\title{
Associations of PYGO2 and PRDM9 Genes Single Nucleotide Polymorphisms with Idiopathic Azoospermia in Iranian Population
}

Sanaz Soleymani Moud

Islamic Azad University Central Tehran Branch

Katayon Kamali Seraji

Islamic Azad University Central Tehran Branch

Mina Ramezani ( $\sim$ mina.ramezani@gmail.com )

Islamic Azad University Central Tehran Branch https://orcid.org/0000-0002-9982-1276

Zeynab Piravar

Islamic Azad University Central Tehran Branch

\section{Research Article}

Keywords: Azoospermia, Pygo2, PRDM9, single nucleotide polymorphisms (SNPs), Spermatogenesis

Posted Date: November 8th, 2021

DOI: https://doi.org/10.21203/rs.3.rs-1053912/v1

License: (a) (i) This work is licensed under a Creative Commons Attribution 4.0 International License. Read Full License 


\section{Abstract \\ Background}

One cause of infertility is azoospermia which affects about $1 \%$ of men in the general population. Nonobstructive azoospermia can be due to genetic disorders. Pygo2 and PRDM9 are two genes involved in spermatogenesis process. The aim of this study was to assess two single nucleotide polymorphism (SNPs) rs61758740, rs61758741 and rs2973631, rs1874165 in these genes respectively.

\section{Methods}

In this case-control study, a total of 100 Iranian patients with idiopathic azoospermia and 100 fertile control subjects were genotyped for Pygo2 rs61758740 and rs61758741 and PRDM9 rs2973631 polymorphism using Tetra-ARMS PCR. PRDM9 rs1874165 polymorphism was assessed by PCR-RFLP method. LH, FSH and testosterone concentrations were measured with electrochemical luminescence $(E C L)$ method.

\section{Results}

Our data indicated a significant increase only in the FSH and LH hormone levels of patients which suggest that the cause of azoospermia is not pre-testicular. rs61758740 ( $\mathrm{T}>\mathrm{C})$ polymorphism in Pygo2 gene was associated with increased risk of azoospermia (OR, 2.359; 95\% Cl $(1.192-4.666) ; \mathrm{p}=0.012)$. Also based on dominant model analysis in rs2973631 of PRDM9 gene, we identified a significant gene frequency difference between cases and control in dominant, recessive and codominant models but dominant, codominant and overdominant models was confirmed for rs1874165.

\section{Conclusion}

Our findings provide evidence for an association between Pygo2 and RDM9 genetic variation and idiophatic azoospermia in Iranian populations. Therefore, SNPs of these genes can be cosidered as a risk factor for male infertility.

\section{Introduction}

Half of all infertility cases are due to men and sperm problems. One of these cases is azoospermia which is testicular failure for a variety of reasons. In this abnormality, sperm production has stopped completely or to a large extent $(1,2)$.

Non-obstructive azoospermia (NOA) accounts for approximately $60 \%$ of azoospermia defects. Despite recent research and remarkable efforts, the reason of some cases of azoospermia is still unknown (3). 
Therefore scientists are looking to discover the pivotal causes of these disorders. To date, the role of different factors in the process of azoospermia has been studied and it has also been observed that many autosomal genes may be involved in male infertility (4). One of these genes is the Pygo2, which has been known to play a main role in idiopathic azoospermia. The Pygo2 gene is located in chromosome 1q21.3 and has three exons and a 3180 bp RNA transcript is made from it. Pygopus (PYGO) is a part of the conserved C-terminal plant homology domain (PHD) that is a family of finger proteins which has two homologues in mammals called Pygo1 and Pygo2 (5). Pygo2 protein is located inside the nucleus in humans and has two domains, the $\mathrm{C}$-terminal PHD zinc finger motif and the $\mathrm{N}$-terminal homology domain (NHD). The PHD domain is a co-activator of the Wnt-pathway which together with the transcription factors such as BCL9, ß-catenin and LEF/TCF forms a transcription complex that facilitates the expression of specific target genes. The NHD domain is involved in histone methylation and transcriptional activation by conscripting histone modification factors (6). It was reported that Pygo2 gene is expressed during the chromatin remodeling of the elongated sperm cell $(7,8)$.

Studies in mice have shown that mutations in this gene can lead to a selective reduction in protamine during the sperm production process and it also exerts changes in highly acetylated histone $\mathrm{H} 3$ which may eventually reduces sperm count or lead to male infertility (6).

The other studied gene which its mutation probably has a fundamental role in inducing idiopathic azoospermia is PRDM9. This gene is located on the 5p14.2 region and contains 11 exons encoding 2 types of RNA and 2 different types of proteins. The protein product of this gene is a zinc finger regulatory protein which during meiosis prophase causes lysine 4 trimethylation of histone 3 (H3K4me3). This gene is responsible for positioning recombination hotspots during the first stage of meiotic cell division and functions through binding a DNA sequence of the meiosis-specific histone methyltransferase $(9,10)$. In the case of $P R D M 9$ mutation in some species including human, the positions of recombination-initiating double-stranded DNA breaks are unable to determine primarily by a specific DNA sequence motif. It has been suggested that $P R D M 9$ gene is expressed in human's testes at the high levels and its disrupting results in complete meiotic arrest (11). Hence, the present study was aimed to investigate the association between single nucleotide polymorphisms in rs61758740 and rs61758741 positions of Pygo2 gene and rs2973631 and rs1874165 positions of PRDM9 gene with idiopathic azoospermia in Iranian population.

\section{Materials And Methods}

\section{Sample collection}

Three milliliters of peripheral blood were collected from 100 infertile men with non-obstructive azoospermia who referred to Roya Fertility Clinic (Qom, Iran) between October 2018 and August 2019. Written informed consent was obtained from all subjects. Additionally, 100 blood samples from fertile men with at least 1 child and no family history of infertility were studied as a control group. All blood samples were collected in EDTA tube and transferred to the laboratory and stored at $-20^{\circ} \mathrm{C}$. 
Scientific use of the samples was approved by the Research Ethics Committee of Islamic Azad Tehran medical Science University (IR.IAU.PS.REC.1398.316) based on provisions of the declaration of Helsinki in 1995. Men were aged between 28-31 years and evaluated by IVF and andrology laboratories to confirm azoospermia. Patients with a history of radiation or chemotherapy, varicocele, Klein-Felter syndrome, cystic fibrosis, and $\mathrm{Y}$ chromosome deletions were excluded from the study.

$\mathrm{LH}, \mathrm{FSH}$ and testosterone levels were measured with electrochemical luminescence (ECL) method (Roche kit, Switzerland).

\section{DNA isolation}

DNA was extracted from peripheral blood leukocytes of the studied samples by standard salt precipitation method (12). Then the DNA quantity was evaluated using a nanodrop spectrophotometer (One C, USA) at 260 and $280 \mathrm{~nm}$ and the quality of DNA was confirmed by agarose gel electrophoresis (Javaherian company, Iran) using $1 \%$ agarose gel.

\section{Primer designing}

Polymorphisms of rs61758740 and rs61758741 in Pygo2 gene and rs2973631 in RPDM9 gene were determined by Tetra Primer amplification refractory mutation system-PCR (4P-ARMS-PCR) analysis. This method applies two primers including inner and outer primers. In the case of rs1874165, due to the lack of a suitable restriction enzyme, restriction fragment length polymorphism method (RFLP) was used. The desired primers were designed by the original software on Tetra Primer ARMS PCR-search website.

Specificity of the primers was checked using BLAST program at http://www.ncbi.nlm.nih.gov/blast. The sequence of primers is shown in Tables 1 and 2. 
Table 1

Sequence of primers used, product size and annealing temperature for T-ARMS PCR.

\begin{tabular}{|c|c|c|c|}
\hline $\begin{array}{l}\text { PYGO2 } \\
\text { gene }\end{array}$ & Primer sequence & $\begin{array}{l}\text { Product size } \\
\text { (bp) }\end{array}$ & $\begin{array}{l}\text { Annealing } \\
\text { temp. }{ }^{\circ} \mathrm{C}\end{array}$ \\
\hline \multirow[t]{4}{*}{ rs61758740 } & $\begin{array}{l}\text { Forward outer primer: } \\
\text { TGGGTGAGATCATGGGACCAAATCCCCC }\end{array}$ & \multirow{4}{*}{$\begin{array}{l}\text { Control } \\
\text { fragment: } 353 \\
\text { T allele: } 214 \\
\text { C allele:193 }\end{array}$} & \multirow[t]{4}{*}{58} \\
\hline & $\begin{array}{l}\text { Reverse outer primer: } \\
\text { AGATGACTTCGGAGCCCCCAAAGTGGGG }\end{array}$ & & \\
\hline & $\begin{array}{l}\text { Forward inner primer: } \\
\text { TGGGGGGGCATGTTGAAAGCAGGGACT }\end{array}$ & & \\
\hline & $\begin{array}{l}\text { Reverse inner primer: } \\
\text { CCACCССССТТССТСССААТСТСТG }\end{array}$ & & \\
\hline \multirow[t]{4}{*}{ rs61758741 } & $\begin{array}{l}\text { Forward outer primer: } \\
\text { GTGCCAAGCTGTTGGCATCTGGAGTGC }\end{array}$ & \multirow{4}{*}{$\begin{array}{l}\text { Control } \\
\text { fragment: } 310 \\
\text { T allele: } 174 \\
\text { C allele: } 192\end{array}$} & \multirow[t]{4}{*}{57} \\
\hline & $\begin{array}{l}\text { Reverse outer primer: } \\
\text { GGCCCACCTTCTCTGTCCCAACGATTTG }\end{array}$ & & \\
\hline & $\begin{array}{l}\text { Forward inner primer: } \\
\text { GCAGTAGAAGCAGGTGGATTCAAGGGATC }\end{array}$ & & \\
\hline & $\begin{array}{l}\text { Reverse inner primer: } \\
\text { CTGGCCCTGGTGGTGAGGATGGGGTGA }\end{array}$ & & \\
\hline
\end{tabular}

Table 2

Sequence of primers used, product size and annealing temperature for T-ARMS PCR and RFLP-PCR.

\begin{tabular}{|c|c|c|c|}
\hline $\begin{array}{l}\text { PRDM9 } \\
\text { gene }\end{array}$ & Primer sequence & $\begin{array}{l}\text { Product size } \\
\text { (bp) }\end{array}$ & $\begin{array}{l}\text { Annealing } \\
\text { temp. }{ }^{\circ} \mathrm{C}\end{array}$ \\
\hline \multirow[t]{4}{*}{ rs2973631 } & $\begin{array}{l}\text { Forward outer primer: } \\
\text { GTCCATTAGGAGAAGAAGCCACACTTCC }\end{array}$ & \multirow{4}{*}{$\begin{array}{l}\text { Control } \\
\text { fragment: } 422 \\
\text { A allele: } 217 \\
\text { G allele: } 260\end{array}$} & \multirow[t]{4}{*}{57} \\
\hline & $\begin{array}{l}\text { Reverse outer primer: } \\
\text { AATCCGCCACTTTCATGACTAGAGATGA }\end{array}$ & & \\
\hline & $\begin{array}{l}\text { Forward inner primer: } \\
\text { TGGACTCTTCTTGCCTTCAGTGATAATGA }\end{array}$ & & \\
\hline & $\begin{array}{l}\text { Reverse inner primer: } \\
\text { AACCCCAAGTGTGTACCTCATTCGTC }\end{array}$ & & \\
\hline \multirow[t]{3}{*}{ rs1874165 } & \multirow{2}{*}{$\begin{array}{l}\text { Forward primer: } \\
\text { GTCCATTAGGAGAAGAAGCCACACTTCC }\end{array}$} & CC: 214,210 & \multirow[t]{3}{*}{50} \\
\hline & & TT:424 & \\
\hline & Reverse primer: TGAGGGAGGCATAATGATAA & CT:424,214,210 & \\
\hline
\end{tabular}


Each PCR contained $4 \mu \mathrm{L}$ of genomic DNA, $10 \mu \mathrm{L}$ of Taq DNA Polymerase $2 X$ Master Mix Red (Amplicon, Denmark) and optimized concentrations of each primer in a final volume of $25 \mu \mathrm{L}$. Amplication was performed on a thermocycler (Kyratec, Australia) with the following program: $95^{\circ} \mathrm{C}$ for 5 min for primary denaturation; denaturation at $93^{\circ} \mathrm{C}$ for $30 \mathrm{~s}$, annealing at the optimum temperature for each primer for 50 $\mathrm{s}$ (Table 1), and extension at $72^{\circ} \mathrm{C}$ for $45 \mathrm{~s}$ for a total of 35 cycles, with a final extension at $72{ }^{\circ} \mathrm{C}$ for 10 min. Then, $10 \mu \mathrm{L}$ of PCR products were separated by running on $1 \%$ agarose gel with DNA size marker $100 \mathrm{bp}$ followed by ethidium bromide staining. DNA bands were visualized and analyzed on uvtransilluminator device. $10 \%$ of the samples were sequenced to confirm the accuracy of the genotypes.

\section{PCR-RFLP method}

PCR-RFLP method was used for the amplification of the SNPs RPDM9 (rs1874165C >T). The restriction enzyme Mboll (Takara, Japan) was selected using NEBcutter V2.0 (BioLabs) software. DNA was run on $2 \%$ of agarose gel, stained and visualized as explained above. In order to check the accuracy of digestion, $10 \%$ of samples were sequenced. Primer sequences, Annealing temperature, and fragments length are shown in Table 2.

\section{Statistical analyses}

Normal levels of hormone were assessed with Kolmogorov-Smirnov test. If the data were normally distributed, independent t-test was used and when the distribution normality test was failed, MannWhitney $U$ test applied. The age values were presented as means and standard deviation (SD). HardyWeinberg equilibrium was estimated by a $\chi 2$ test to compare observed and expected genotype frequencies among the cases and controls. Odds ratios (ORs) and 95\% confidence intervals ( $\mathrm{Cl}$ ) were determined using unconditional logistic regression analysis to assess the SNPs' effects on the risk of azoospermia. All statistical analysis was carried out in SPSS 24 (SPSS, Chicago, IL, USA) and online SNPstat (https://www.snpstats.net) software. P<0.05 considered as significant.

\section{Results}

The subjects under study consisted of 100 cases and 100 controls. The mean age of case and control individuals was $29.37 \pm 1.54$ and $29.31 \pm 1.53$ years respectively. Independent t test indicated that the mean age difference was not significant between two groups of men $(P=0.783)$.

Comparison of FSH and LH with Mann-Whitney $\mathrm{U}$ test in the control and case groups demonstrated that the level of these hormones is significantly higher in the case group. But t-test analysis for testosterone did not show significant difference between the two groups (Figure 1).

In this study two SNPs of Pygo2 gene (rs61758740 and rs61758741) were studied. All the rs61758740 SNPs were in agreement with the Hardy-Weinberg equilibrium, both in the cases, controls and whole population $(p>0.05)$. The observed frequency difference between two populations was significant $(p=0.012)$. Odds ratio calculation indicated people with the CT genotype are 2.359 times more likely to develop azoospermia. The genotypic and allelic frequencies polymorphisms are listed in Table 3. 
According to the Hardy-Weinberg test about rs61758741, the control population was in equilibrium ( $p>0.05$ ). But both whole population and the patient were not in agreement with Hardy-Weinberg equilibrium $(p<0.05)$. The observed frequency difference between cases and control was similar $(p=0.355)$. Odds ratio calculation indicated people with the CT genotype are 1.332 times more likely to develop azoospermia (Table 4).

Table 3: Allele and genotype frequencies of rs61758740 (C>T) and association with azoospermia risk.

\begin{tabular}{|c|c|c|c|c|}
\hline \multirow[t]{2}{*}{ Genotype } & Case & Control & \multirow[t]{2}{*}{ OR (95\% Cl) } & \multirow[t]{2}{*}{ P-Value } \\
\hline & $\mathrm{N}=100(\%)$ & $\mathrm{N}=100(\%)$ & & \\
\hline \multicolumn{5}{|c|}{ Pygo2 rs61758740 (C>T) } \\
\hline $\mathrm{CC}$ & 69 (69\%) & $84(84 \%)$ & \multirow[t]{2}{*}{$2.359(1.192-4.666)$} & \multirow[t]{2}{*}{0.012} \\
\hline CT & $31(31 \%)$ & $16(16 \%)$ & & \\
\hline \multicolumn{5}{|l|}{ Allele } \\
\hline C & $169(84.5 \%)$ & $184(92 \%)$ & \multirow[t]{2}{*}{$2.109(1.114-3.994)$} & \multirow[t]{2}{*}{0.02} \\
\hline $\mathrm{T}$ & 31 (15.5\%) & $16(8 \%)$ & & \\
\hline
\end{tabular}

On the other part of the research two SNPs of PRDM9 (rs2973631 and rs1874165) gene were studied. According to Hardy Weinberg test, case and control populations were not in equilibrium for rs2973631 and rs1874165.

The relative risk of genotypes resulting from these polymorphisms to develop azoospermia was examined by unconditional logistic regression test. In this test, four different hereditary models (dominant, recessive, codominant and overdominant) were analyzed. Findings about rs2973631 indicated that there was significant difference between the genotypic frequency of case and control individuals in the dominant, recessive and codominant models (Table 5). Results of the genotypic frequency for rs 1874165 showed significant difference in the dominant, codominant and overdominant models (Table 6 and 7).

Table 4: Allele and genotype frequencies of rs61758741 (C>T) and association with azoospermia risk. 


\begin{tabular}{|c|c|c|c|c|}
\hline \multirow[t]{2}{*}{ Genotype } & Case & Control & \multirow[t]{2}{*}{ OR $(95 \% \mathrm{Cl})$} & \multirow[t]{2}{*}{ P-Value } \\
\hline & $\mathrm{N}=100(\%)$ & $\mathrm{N}=100(\%)$ & & \\
\hline \multicolumn{5}{|c|}{$\begin{array}{l}\text { Pygo2 rs61758741 } \\
(\mathrm{C}>\mathrm{T})\end{array}$} \\
\hline TT & $67(67 \%)$ & $73(73 \%)$ & \multirow[t]{2}{*}{$1.332(0.726-2.444)$} & \multirow[t]{2}{*}{0.355} \\
\hline TC & $33(33 \%)$ & $27(27 \%)$ & & \\
\hline \multicolumn{5}{|l|}{ Allele } \\
\hline $\mathrm{T}$ & $\begin{array}{l}167 \\
(83.5 \%)\end{array}$ & $\begin{array}{l}173 \\
(86.5 \%)\end{array}$ & \multirow[t]{2}{*}{$1.266(0.73-2.197)$} & \multirow[t]{2}{*}{0.401} \\
\hline C & $33(16.5 \%)$ & $27(13.5 \%)$ & & \\
\hline
\end{tabular}

Table 5

The relative risk of genotypes for azoospermia of rs2973631 in PRDM9 gene.

\begin{tabular}{|c|c|c|c|c|c|}
\hline Model & Genotype & Azoospermia & Control & OR $(95 \% \mathrm{Cl})$ & P-value \\
\hline \multirow[t]{3}{*}{ Codominant } & AA & 57 & 40 & 1.00 & \multirow[t]{3}{*}{0.014} \\
\hline & $A G$ & 30 & 32 & $0.658(0.346-1.25)$ & \\
\hline & GG & 13 & 28 & $0.326(0.151-0.705)$ & \\
\hline \multirow[t]{2}{*}{ Dominant } & AA & 57 & 40 & 1.00 & \multirow[t]{2}{*}{0.016} \\
\hline & $A G-G G$ & 43 & 60 & $0.503(0.286-0.883)$ & \\
\hline \multirow[t]{2}{*}{ Recessive } & GG & 13 & 28 & $2.603(1.257-5.391)$ & \multirow[t]{2}{*}{0.009} \\
\hline & AG-AA & 87 & 72 & 1.00 & \\
\hline \multirow[t]{2}{*}{ Overdominant } & $A A-G G$ & 70 & 68 & 1.00 & \multirow[t]{2}{*}{0.76} \\
\hline & $A G$ & 30 & 32 & $0.911(0.5-1.695)$ & \\
\hline \multicolumn{6}{|l|}{ Allele } \\
\hline A & & 144 & 112 & $0.495(0.326-0.75)$ & 0.001 \\
\hline G & & 56 & 88 & & \\
\hline
\end{tabular}


Table 6

The relative risk of genotypes for azoospermia of rs1874165 in PRDM9 gene.

\begin{tabular}{|c|c|c|c|c|c|}
\hline Model & Genotype & Azoospermia & Control & OR $(95 \% \mathrm{Cl})$ & P-value \\
\hline \multirow[t]{3}{*}{ Codominant } & $\mathrm{CC}$ & 65 & 44 & 1.00 & \multirow[t]{3}{*}{0.005} \\
\hline & $\mathrm{CT}$ & 20 & 40 & $0.338(0.175-0.654)$ & \\
\hline & $\mathrm{TT}$ & 15 & 16 & $0.635(0.285-1.415)$ & \\
\hline \multirow[t]{2}{*}{ Dominant } & $\mathrm{CC}$ & 65 & 44 & 1.00 & \multirow[t]{2}{*}{0.003} \\
\hline & CT-TT & 35 & 56 & $0.423(0.239-0.748)$ & \\
\hline \multirow[t]{2}{*}{ Recessive } & TT & 15 & 16 & $1.079(0.502-2.322)$ & \multirow[t]{2}{*}{0.845} \\
\hline & CT-CC & 85 & 84 & 1.00 & \\
\hline \multirow[t]{2}{*}{ Overdominant } & CC-TT & 80 & 60 & 1.00 & \multirow[t]{2}{*}{0.002} \\
\hline & CT & 20 & 40 & $0.375(0.199-0.706)$ & \\
\hline \multicolumn{6}{|l|}{ Allele } \\
\hline C & & 150 & 128 & \multirow[t]{2}{*}{$0.593(0.385-0.912)$} & \multirow[t]{2}{*}{0.017} \\
\hline $\mathrm{T}$ & & 50 & 72 & & \\
\hline
\end{tabular}

Table 7

Minor Allele Frequency in the studied population and Hardy-Weinberg tests for the study of population.

\begin{tabular}{|lll|}
\hline SNP & MAF & HWEP \\
\hline rs61758740 & 0.0018 & 0.059 \\
\hline rs61758741 & 0.0004 & 0.012 \\
\hline rs2973631 & 0.1116 & 0.0001 \\
\hline rs1874165 & 0.2041 & 0.0001 \\
\hline $\begin{array}{l}\text { SNP; Single nucleotide polymorphism, MAF; Minor allele frequency, and HWE P; Hardy-Weinberg } \\
\text { equilibrium P value. }\end{array}$ & \\
\hline
\end{tabular}

Minor allele frequency for PYGO2 SNPs were rs61758740: $\mathrm{C}>\mathrm{T}$ ( $\mathrm{T}=0.0018 / 9 ; 1000 \mathrm{Genomes})$, rs61758741: $\mathrm{T}>\mathrm{C}(\mathrm{C}=0.0004 / 2 ; 1000 \mathrm{Genomes})$, and $P R D M 9$ SNPs were rs2973631: $\mathrm{C}>\mathrm{T}(\mathrm{T}=0.1116 / 559$; 1000Genomes), rs1874165: C>T (C=0.2041/1022; 1000Genomes) (Table 7).

\section{Discussion}

Our data demonstrated a significant increase in FSH and LH hormone levels of patient men compared to the control $(p<0.001)$ but testostrone levels did not indicate a significant difference between two groups. This suggests that the cause of azoospermia is not pre-testicular. 
Male fertility is a very complex process that requires about 2,000 genes which act in multiple pathways controlling spermatogenesis as well as testicular support and development (13). Meiosis in humans is controlled by many genes, some of which are expressed throughout meiosis and some at specific stages of spermatogenesis (14). In the recent years many studies have been done on the role of genetics in spermatogenesis and male infertility and it is estimated that genetic factors cause 15 to $30 \%$ of male infertility $(1,15)$.

One of the causes of male infertility is azoospermia which among them idiopathic azoospermia is a complex condition with unknown causes. Idiopathic azoospermia is a multifactorial disease which involves genetic and epigenetic background. Epigenetic dysfunction refers to abnormal histones and protamine modification or abnormal DNA methylation and hypermethylation as well as abnormality in chromatin remodeling (16).

The Pygo2 gene expression is needed for the chromatin remodeling of the sperm cells $(5,17)$. In the current study of pygo2 SNPs, it was demonstrated that individuals with CT genotype of rs61758740 (M141I) and rs61758741 (K261E) are significantly more likely to develop azoospermia. However, a $\chi 2$ test only for rs61758740 could finds difference between observed and expected genotype frequencies among cases and controls.

In agreement with our finding, Ge et al. identified these two non-synonymous SNPs in men with azoospermia and severe oligospermia. SNP rs61758740 is located at nucleotide position 2206 and results the replacement of a hydrophobic by a hydrophilic amino acid and SNP rs61758741 is located at nucleotide position 2564 and leads to the replacement of a basic amino acid with an acidic one (7).

Studies in mice have shown that mutations in this gene can lead to a selective decrease in protamine during the sperm production process. It ultimately reduces the expression of the $\mathrm{H} 1 \mathrm{fnt}, \mathrm{PRM} 1$ and PRM2 in meiotic division and brings about lower sperm count or infertility through disruption of chromatin remodeling $(5,18)$.

In most mammalian, double- strand breaks (DSBs) and recombination in germ cell meiosis occurs at preferred locations named hotspots, whose sites become marked by H3K4me3. The protein which determines these hotspots is histone methyl transferase PRDM9 (19). Recently Chen et al. highlighted pivotal role of PRDM9- mediated H3K4me3 in directing DSB fate and crossovers homeostatic control (Chen 10).

A study by Zhang et al. Showed that normal synapses in recombination depend on the function of PRDM9 in spermatocytes (20). Therefore PRDM9 may have an important role in male infertility and testicular dysfunction.

The findings of the current study indicated that there is a significant difference in rs1874165 and rs2973631 polymorphisms in the PRDM9 gene between healthy and azoospermic groups. As presented in the logistic regression analyze reported here both SNPs of PRDM9 indicated significant difference 
between control and patient groups at least in the codominant and dominant models. Therefore we identified different variants of these SNPs in a population of Iranian non obstructive azoospermia men which could be associated with the defective spermatogenesis. In contrast, in the He et al. study, no association was found between these two SNPS and azoospermia. Several factors including sample size, ethnicity and study method may justify the discrepancy between two reports (9). Recently it is revealed that histone methyltransferase PRDM9 is not essential for meiotic recombination in male mice and it can occur at non PRDM9- mediated H3k4me3 such as promoters and other functional sites (21). However, in humans the exact role of $P R D M 9$ gene during meiosis is not obvious but some researchers have approved the essential role of this gene in determination of DNA recombination initiating DSBs (22). According to the position of both SNPs within the uncoding regions (rs2973631 at 3'UTR and rs1874165 at intron) the expression of $P R D M 9$ gene may be affected through spatial pattern variation.

Of note that study of the PRDM9 gene variants and sequencing of the whole PRDM9 gene within the large azoospermia cases should be put in the prospective account to know if any direct mutation is also associated with defective spermatogenesis.

\section{Conclusion}

This is the first study to be performed on the association of rs61758740 and rs61758741 SNPs of PYGO2 gene with azoospermia in Iranian population. It was found that genotypic frequency of rs61758740 could be significantly different in the cases and control groups and men with the CT genotype are 2.359 times more likely to develop azoospermia. However, the observed frequency difference between the two groups in rs61758741 was not significant. It seems that the significant frequency difference in rs 61758740 would likely to be a good prognosis criterion for the existence and relationship of this polymorphism with azoospermia among Iranian populations.

Our results also suggest that the PRDM9 rs2973631 and rs1874165 gene polymorphisms have clinical importance in the prediction of azoospermia among the Iranian men and should take into account.

\section{Declarations}

Acknowledgment This work was conducted by private budget. The authors are grateful to Infertility Treatment Centre ACECR Qom and Central Tehran Islamic Azad University. Authors declare there are no conflicts of interest.

Conflicts of interests Ms.Sanaz soleymani moud declares that she has no conflict of interest. Ms.Katayon Kamali Seraji declares that she has no conflict of interest. Dr.Mina Ramezani declares that she has no conflict of interest. Dr.Zeynab Piravar declares that she has no conflict of interest.

Ethical approval All procedures performed in studies involving human participants were in accordance with the ethical standards of the institutional and/or national research committee and with the 1964 Helsinki declaration and its later amendments or comparable ethical standards. 
Informed consent Informed consent was obtained from all individual participants included in the study.

\section{References}

1-Tahmasbpour, E., D. Balasubramanian, et al. (2014). "A multi-faceted approach to understanding male infertility: gene mutations, molecular defects and assisted reproductive techniques (ART). Journal of assisted reproduction and genetics 31(9): 1115-1137. https://doi.org/doi:10.1007/s10815-014-0280-6.

2-Cerván-Martín M, Castilla JA, Palomino-Morales RJ, Carmona FD. Genetic landscape of nonobstructive azoospermia and new perspectives for the clinic. Journal of clinical medicine. 2020 Feb;9(2):300. https://doi.org/doi: 10.3390/jcm9020300.

3-Lotti F, Maggi M. Sexual dysfunction and male infertility. Nature Reviews Urology. 2018 May;15(5):287307. https://doi.org /doi: 10.1038/nrurol.2018.20.

4-Cioppi F, Rosta V, Krausz C. Genetics of Azoospermia. International Journal of Molecular Sciences. 2021 Jan;22(6):3264. https://doi.org /doi: 10.3390/ijms22063264.

5-Nair M, Nagamori I, Sun P, Mishra DP, Rhéaume C, Li B, Sassone-Corsi P, Dai X. Nuclear regulator Pygo2 controls spermiogenesis and histone H3 acetylation. Developmental biology. 2008 Aug 15;320(2):446-55. https://doi.org /doi: 10.1016/j.ydbio.2008.05.553 .

6-Cantù C, Valenta T, Hausmann G, Vilain N, Aguet M, Basler K. The Pygo2-H3K4me2/3 interaction is dispensable for mouse development and Wnt signaling-dependent transcription. Development. 2013 Jun 1;140(11):2377-86. https://doi.org/doi: 10.1242/dev.093591.

7-Ge SQ, Liu LH, Aston KI, Simon L, Jenkins TG, Emery BR, Carrell DT. Associations of single nucleotide polymorphisms in the Pygo2 coding sequence with idiopathic oligospermia and azoospermia. Genet Mol Res. 2015 Aug 7;14(3):9053-61.b. https://doi.org /doi: 10.4238/2015.August.7.14.

8- Wang T, Gao H, Li W, Liu C. Essential role of histone replacement and modifications in male fertility. Frontiers in genetics. 2019 Oct 8;10:962. https://doi.org /doi: 10.3389/fgene.2019.00962.

9- He XJ, Ruan J, Du WD, Cao YX, Chen G, Zuo XB, Peng YW, Wu H, Song B, Zhang XJ. PRDM9 gene polymorphism may not be associated with defective spermatogenesis in the Chinese Han population. Systems biology in reproductive medicine. 2013 Feb 1;59(1):38-41. https://doi.org / doi: 10.3109/19396368.2012.723793.

10-Chen Y, Lyu R, Rong B, Zheng Y, Lin Z, Dai R, Zhang X, Xie N, Wang S, Tang F, Lan F. Refined spatial temporal epigenomic profiling reveals intrinsic connection between PRDM9-mediated H3K4me3 and the fate of double-stranded breaks. Cell research. 2020 Mar;30(3):256-68. https://doi.org /doi:

10.1038/s41422-020-0281-1. 
11-Irie S, Tsujimura A, Miyagawa Y, Ueda T, Matsuoka Y, Matsui Y, Okuyama A, Nishimune Y, Tanaka H. Single-nucleotide polymorphisms of the PRDM9 (MEISETZ) gene in patients with nonobstructive azoospermia. Journal of andrology. 2009 Jul 8;30(4):426-31. https://doi.org /doi: 10.2164/jandrol.108.006262.

12-Miller SA, Dykes D, Polesky H. A simple salting out procedure for extracting DNA from human nucleated cells. Nucleic acids res. 1988;16(3):1215. https://doi.org /doi: 10.1093/nar/16.3.1215.

13-Hargreave TB. Genetic basis of male fertility. 2000. Br Med Bull. 56:650-71. https://doi.org / doi: $10.1258 / 0007142001903454$.

14-Nishimune $\mathrm{Y}$, Tanaka $\mathrm{H}$. Infertility caused by polymorphisms or mutations in spermatogenesis-specific genes. 2006. J Androl. 27:326-34. https://doi.org /doi: 10.2164/jandrol.05162.

15-Kamaliyan Z, Pouriamanesh S, Amin-Beidokhti M, Rezagholizadeh A, Mirfakhraie R. HIWI2 rs508485 polymorphism is associated with non-obstructive azoospermia in iranian patients. Reports of biochemistry \& molecular biology. 2017 Apr;5(2):108.

16-Gunes S, Esteves SC. Role of genetics and epigenetics in male infertility. Andrologia. 2021 Feb;53(1):e13586. https://doi.org /doi: 10.1111/and.13586.

17-Dumasia K, Kumar A, Deshpande S, Balasinor NH. Estrogen, through estrogen receptor 1, regulates histone modifications and chromatin remodeling during spermatogenesis in adult rats. Epigenetics. 2017 Nov 2;12(11):953-63. https://doi.org /doi: 10.1080/15592294.2017.1382786.

18- Blanco M, Cocquet J. Genetic Factors Affecting Sperm Chromatin Structure. Genetic Damage in Human Spermatozoa. 2019:1-28. https://doi.org/doi: 10.1007/978-3-030-21664-1_1.

19-Sun F, Fujiwara Y, Reinholdt LG, Hu J, Saxl RL, Baker CL, Petkov PM, Paigen K, Handel MA. Nuclear localization of PRDM9 and its role in meiotic chromatin modifications and homologous synapsis. Chromosoma. 2015 Sep;124(3):397-415. https://doi.org /doi: 10.1007/s00412-015-0511-3.

20-Jing Zhang and Dang-xia Zhou \& Hai-xu Wang \& Zhao Tian. An association study of SP011 gene single nucleotide polymorphisms with idiopathic male infertility in Chinese Han population. 2011. J Assist Reprod Genet . 28:731-736. https://doi.org /doi: 10.1007/s10815-011-9571-3.

21-Mihola O, Pratto F, Brick K, Linhartova E, Kobets T, Flachs P, Baker CL, Sedlacek R, Paigen K, Petkov PM, Camerini-Otero RD. Histone methyltransferase PRDM9 is not essential for meiosis in male mice. Genome research. 2019 Jul 1;29(7):1078-86. https://doi.org /doi: 10.7554/eLife.53459.

22-Grey C, Baudat F, de Massy B. PRDM9, a driver of the genetic map. PLoS genetics. 2018 Aug 30;14(8):e1007479. https://doi.org /doi: 10.1371/journal.pgen.1007479. 
Figures
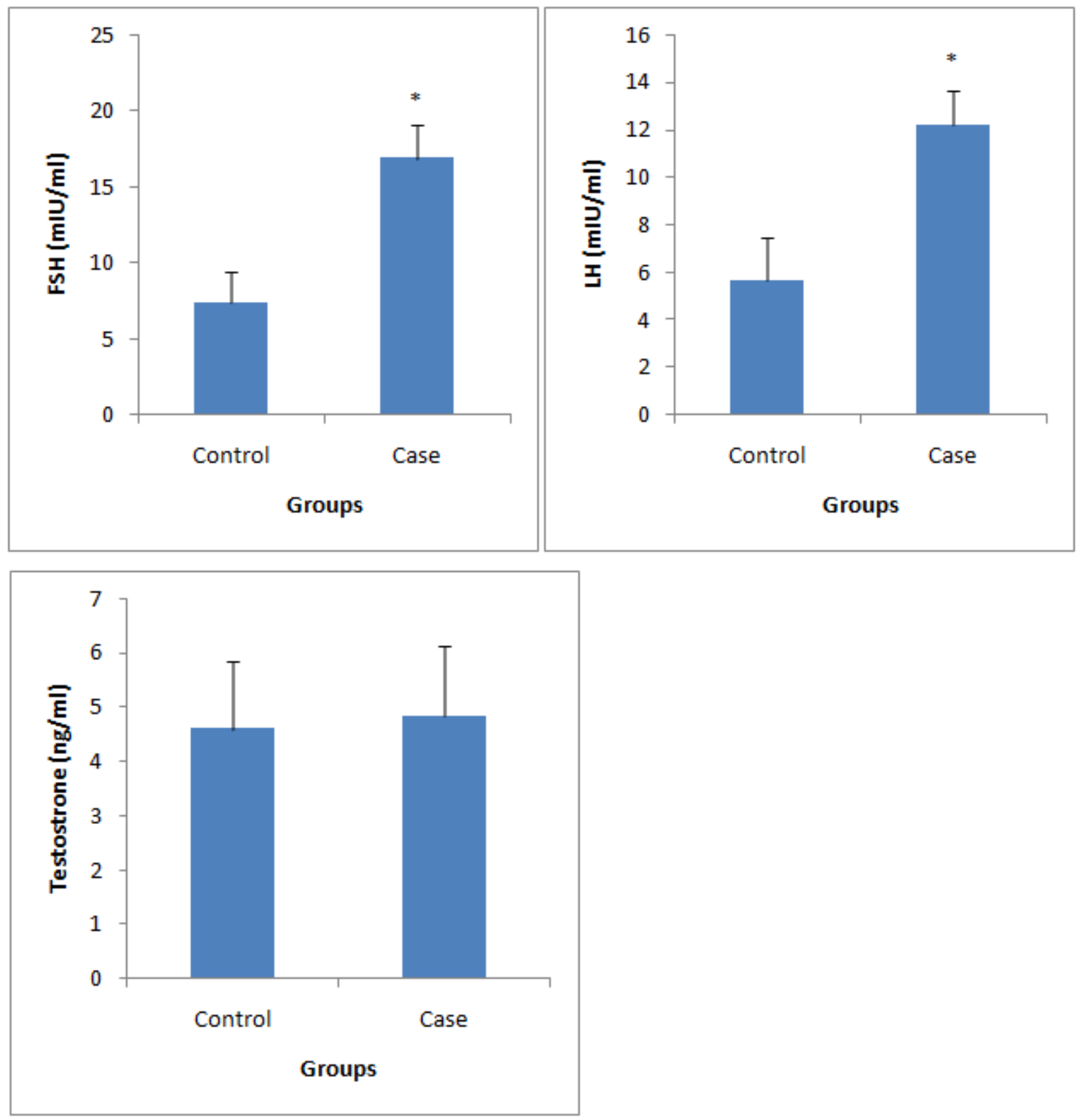

Figure 1

$\mathrm{FSH}, \mathrm{LH}$ and testosterone levels in the control and case groups ( $\mathrm{a} . \mathrm{b}$ and $\mathrm{c}$ ) respectively. Data are Mean \pm $S D, * P<0.001$. 